\title{
ANALISIS KORELASI FAKTOR PERILAKU KONSUMEN TERHADAP KEPUTUSAN PENGGUNAAN TEKNOLOGI KOMUNIKASI VoIP
}

\author{
Budi Yulianto \\ Jurusan Teknik Informatika, School of Computer Science, Bina Nusantara University \\ Jln. K.H. Syahdan No. 9, Palmerah, Jakarta Barat, 11480 \\ laboratory@binus.ac.id
}

\begin{abstract}
The advancement of communication technology that is combined with computer and the Internet brings Internet Telephony or VoIP (Voice over Internet Protocol). Through VoIP technology, the cost of telecommunications in particular for international direct dialing (IDD) can be reduced. This research analyzes the growth rate of VoIP users, the correlation of the consumer behavior towards using VoIP, and cost comparisons of using telecommunication services between VoIP and other operators. This research is using descriptive analysis method to describe researched object through sampling data collection for hypothesis testing. This research will lead to the conclusion that the use of VoIP for international area will be more advantageous than the use of other operators of GSM (Global System for Mobile), CDMA (Code Division Multiple Access), or the PSTN (Public Switched Telephone Network).
\end{abstract}

Keywords: internet telephony, Voice over Internet Protocol, Consumer behavior, telecommunication, descriptive analyst, Internasional Direct Diali

\begin{abstract}
ABSTRAK
Perkembangan teknologi komunikasi disertai perkembangan komputer dan Internet memunculkan Internet Telephony atau VoIP (Voice over Internet Protocol). Melalui teknologi VoIP tersebut, biaya telekomunikasi khususnya untuk sambungan langsung internasional (SLI) dapat ditekan. Penelitian ini menganalisis tingkat pertumbuhan pengguna VoIP, korelasi antara perilaku konsumen terhadap keputusan menggunakan VoIP, serta perbandingan biaya penggunaan jasa telekomunikasi pada VoIP dengan operator lain. Penelitian ini menggunakan menggunakan metodologi analisis deskriptif yang bertujuan menggambarkan suatu kajian melalui pengumpulan data sampel untuk pengujian hipotesis. Penelitian ini akan menghasilkan kesimpulan bahwa penggunaan VoIP untuk area internasional akan lebih menguntungkan dibandingkan dengan penggunaan operator GSM (Global System for Mobile), CDMA (Code Division Multiple Access), ataupun PSTN (Public Switched Telephone Network).
\end{abstract}

Kata kunci: internet telephony, Voice over Internet Protocol, perilaku konsumen, telekomunikasi, analisis deskriptif, Sambungan Langsung Internasional 


\section{PENDAHULUAN}

Perkembangan teknologi komunikasi disertai dengan perkembangan teknologi komputer telah memunculkan teknologi VoIP (Voice over Internet Protocol) atau telepon Internet yang memungkinkan komunikasi suara melalui Internet (Cisco Systems, 2004). Teknologi VoIP mengubah data analog (suara dari pembicara) menjadi digital (data atau paket pada Internet) dan kemudian dikonversikan kembali ke data analog, yakni suara ke pendengar (Sri, 2005). Penggunaan VoIP memerlukan beberapa perangkat dasar berupa komputer, modem, fasilitas Internet, dan perangkat lunak pendukung VoIP yang disebut softphone.

Layanan VoIP sangat efisien untuk komunikasi jarak jauh, khususnya panggilan internasional karena jenis panggilan tersebut membutuhkan biaya yang mahal jika dilakukan dengan operator telekomunikasi yang berbasiskan GSM, CDMA, atau PSTN. Jika menggunakan layanan Internet dengan hitungan pembayaran per waktu atau per paket, penggunaan VoIP untuk panggilan dekat akan lebih mahal, namun untuk panggilan jauh akan lebih murah. Beda halnya dengan penggunaan layanan Internet yang bersifat unlimited, penggunaan VoIP akan lebih murah baik untuk panggilan lokal, interlokal, ataupun internasional. Di dunia internasional VoIP telah menjadi isu panas dan menawarkan terobosan telekomunikasi murah (Hidayat, 2003). Di Indonesia perkembangan VoIP selama 10 tahun telah memberikan layanan komunikasi murah ke perangkat telepon namun mengalami hambatan baik dari sisi regulasi pemerintah maupun kemampuan penggunaan teknologi pada masyarakat (Rahardja, 2007).

Penelitian ini bertujuan untuk mengetahui korelasi antara perilaku konsumen terhadap keputusan menggunakan VoIP. Selain itu penelitian ini juga menghasilkan faktor apa saja yang menjadi pendukung dan penghambat tingkat pertumbuhan penggunaan teknologi telekomunikasi VoIP, dan perbandingan tarif atau biaya komunikasi untuk panggilan lokal, interlokal, dan internasional pada VoIP dengan operator telekomunikasi GSM, CDMA, dan PSTN.

\section{Tinjauan Pustaka}

VoIP (Voice over Internet Protocol), disebut juga IP Telephony atau Internet Telephony adalah teknologi yang mengirim suara dalam bentuk paket data melalui jaringan atau media Internet secara real time (Pustekkom Depdiknas, 2007). Layanan VoIP yang umum saat ini dilakukan dengan tiga metode, yaitu menggunakan Analog Telephone Adaptor (ATA), IP Phone, atau komunikasi antarkomputer (Computer-to-Computer). Beberapa keuntungan finansial dari VoIP adalah tarif SLJJ dan SLI dapat ditekan hingga 1/8 atau bahkan 1/10 dari tarif komunikasi (Onno, 2007); dan biaya komunikasi keseluruhan dapat ditekan hingga 90\% sehingga dapat menyebabkan return on investment (ROI) dalam kurun waktu kurang dari satu tahun (Goncalves, 1999). Adapun beberapa kekurangan dari VoIP adalah kualitas suara umumnya tidak sejernih operator telekomunikasi karena efek dari kompresi dan jeda suara (kualitas suara akan jernih jika koneksi Internet berupa pitalebar/broadband); regulasi dari pemerintah RI yang membatasi penggunaan VoIP untuk disambung ke jaringan milik operator telekomunikasi lain (seperti Telkom); dan jika belum terhubung secara 24 jam ke Internet perlu janji untuk saling berhubungan.

Penelitian sebelumnya menunjukkan bahwa kendala konsumen tidak menggunakan VoIP adalah karena kualitas suara yang dihasilkan tidak sebaik jaringan operator (Alwakeel \& Prasetijo, 2009). Hal ini bisa disebabkan oleh keterbatasan koneksi Internet yang ada pada jaringan operator selular di area (Yulianto, 2010). Suara yang dihasilkan melalui VoIP juga sering menghasilkan gema sehingga mengganggu kejelasan suara yang didengar oleh lawan bicara (Ravichandran, 2006). Selain itu, keterbatasan kemampuan perangkat mobile dan aplikasi softphone yang tersedia juga menjadi salah satu faktor pelannya pertumbuhan pengguna komunikasi VoIP (Singh, Atwal, \& Sohis, 2007). 


\section{METODE}

Metodologi penelitian ini menggunakan metode deskriptif, yakni metodologi riset yang bertujuan untuk menggambarkan sesuatu (Hasan, 2002). Tahapan awal penelitian ini dimulai dari perumusan masalah, tujuan, dan dilanjutkan dengan menentukan desain penelitian. Tahap selanjutnya adalah pengumpulan data yang dilakukan dengan menggunakan metode kuesioner dan pengumpulan data sekunder. Pembuatan kuesioner penelitian menggunakan dasar perilaku konsumen demi menjawab permasalahan penelitian. Responden yang dituju dalam penelitian ini adalah para pelanggan (konsumen) layanan komunikasi operator selular di Indonesia dengan menggunakan rumus Ukuran Sampel oleh Paguso. Hasil analisis dari data tersebut digunakan untuk menguji hipotesis tentang korelasi perilaku konsumen terhadap keputusan dalam menggunakan VoIP.

Model analisis yang digunakan mencakup komponen perilaku konsumen, yaitu faktor eksternal, internal psikologis, dan jati diri responden. Pada tahapan analisis ini dilakukan proses pengolahan data yang meliputi coding (pengodean), data entry (memasukkan data), cleaning dan editing data (penyeleksian dan pembersihan data yang salah), dan data processing (pemrosesan data menggunakan perangkat SPSS) menggunakan analisis deskriptif frekuensi dan analisis crosstab (custom tables). Pada tahapan akhir pengujian korelasi menggunakan tes kebebasan $\chi^{2}\left(\chi^{2}\right.$ test of independence), yaitu tes yang digunakan untuk menguji tingkat kebebasan atau hubungan terhadap dua kategori variabel (Levine, et al, 2005). Pada tahapan ini akan diuji tingkat korelasi terhadap keputusan konsumen menggunakan VoIP.

\section{Kerangka Pikir}

Kerangka 238yste menggambarkan kerangka utama yang digunakan dalam menganalisis kajian yang dilakukan dalam penelitian ini. Kegiatan penelitian ini dimulai dari perumusan masalah dan tujuan, disain penelitian secara deskriptif, pengumpulan data, analisis perilaku konsumen, pembahasan hasil, dan menghasilkan kesimpulan dan saran. Pada tahapan analisis perilaku konsumenmerupakan faktor yang sangat penting dalam menentukan tingkat pertumbuhan pengguna VoIP karena berkaitan dengan kebutuhan konsumensekaligus mengetahui korelasi antara perilaku konsumen dengan keputusan menggunakan VoIP. Selain itu, analisis perilaku konsumen juga menghasilkan perbandingan biaya antara VoIP dengan operator telekomunikasi lain.

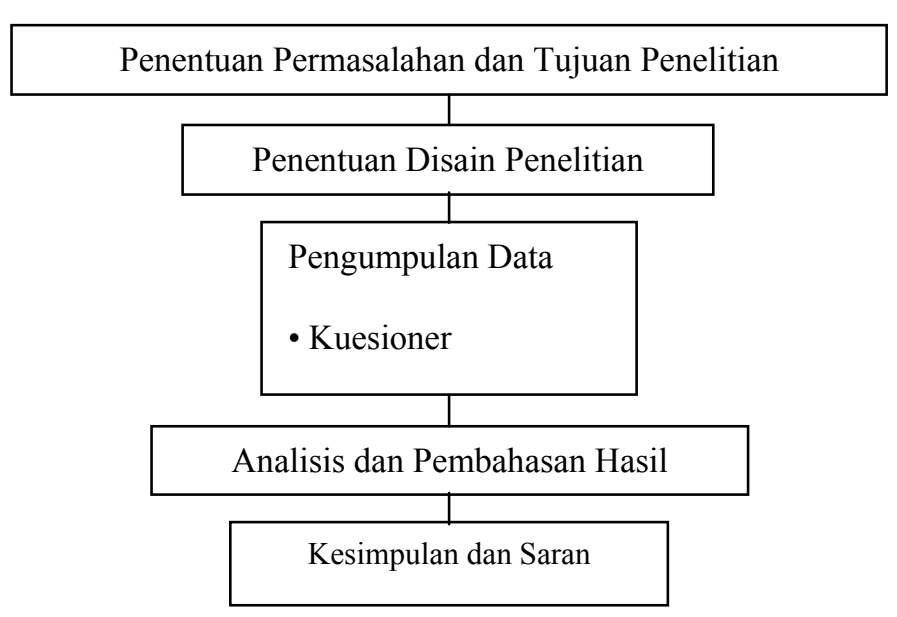

Gambar 1 Kerangka Pikir 


\section{Hipotesis}

Penelitian ini menguji hipotesis tentang korelasi antara perilaku konsumen terhadap keputusan dalam menggunakan VoIP:

$\mathrm{H}_{0}$ : Perilaku konsumen mempengaruhi keputusan menggunakan VoIP

$\mathrm{H}_{1}$ : Perilaku konsumen tidak mempengaruhi keputusan menggunakan VoIP

\section{Model Analisis}

Pada tahapan analisis, dari Kerangka Pikir di atas, dilakukan model analisis yang terdiri atas beberapa komponen penting. Diawali dari consumer 239ystem239r (perilaku konsumen) yang dipengaruhi oleh eksternal, internal psikologis, dan jati diri pribadi. Dan faktor eksternal yaitu lingkungan dan kelompok acuan.

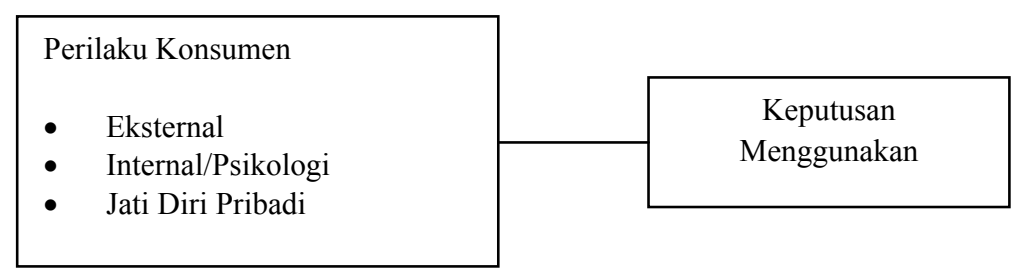

Gambar 2 Model Analisis

Faktor internal psikologis konsumen dilatarbelakangi motivasi dan persepsi konsumen tersebut dalam melihat dan memakai VoIP saat ini. Selanjutnya faktor jati diri pribadi yang termasuk di dalamnya adalah pekerjaan, gaya hidup, dan ekonomi. Keseluruhan faktor-faktor tersebut mengarahkan konsumen dalam keputusan menggunakan teknologi telekomunikasi VoIP.

\section{Metode Pengumpulan Data}

Untuk mendapatkan informasi dan data-data yang diperlukan dalam penelitian ini, maka dilakukan pengumpulan data melalui studi pustaka dan kuesioner. Pada tahapan studi pustaka (library research), diperoleh data sekunder yaitu data yang diperoleh melalui data yang telah diteliti dan dikumpulkan oleh pihak lain yang berkaitan dengan permasalahan penelitian ini. Bahan data sekunder meliputi text books, majalah, artikel, 239yste, dan data online di Internet.

Pada tahapan kuesioner dilakukan penyusunan berdasarkan definisi perilaku konsumen (Schiffman, 2007) dan penyusunan variabel dan indikator penelitian menggunakan kerangka teori konsumen. Tata letak pertanyaan dalam kuesioner menggunakan metode Attitude and Usage yaitu membagi pertanyaan ke dalam empat tahap yaitu awareness (kesadaran), trial (percobaan), usage (pemakaian) dan retention (kesetiaan), agar pertanyaan kuesioner lebih terstruktur mulai dari responden yang hanya mengetahui tentang VoIP, pernah mencoba, memakai, dan tetap bertahan menggunakan VoIP. Peneliti menyebarkan kuesioner pada responden yang telah mengenal pemakaian Internet, 239ystem239r, dan handphone.

\section{Metode Analisis Data}

Metode analisis data dalam kajian ini akan menggunakan metode analisis deskriptif dengan memakai alat bantu program SPSS 16 untuk mendapatkan data frekuensi/deskriptif dari hasil penelitian. Tahapan yang digunakan dalam proses pengolahan data meliputi (1) Coding, dimana pengkodean dilakukan untuk dapat memasukan data secara kuantitatif, misalkan kode 'a' untuk Ya 
dan kode 'b' untuk Tidak; (2) Data entry, pengkodean dimasukkan ke dalam 240ystem SPSS 16; (3) Cleaning dan editing data, dilakukan penyeleksian dan pembersihandari kesalahan pada proses input yang mungkin terjadi; dan (4) data processing, data yang telah bersih kemudian diproses dengan SPSS 16 menggunakan analisis deskriptif frekuensi dan analisis crosstab (custom tables) untuk menghasilkan output berupa tabel atau grafik.

\section{Variabel}

Berdasarkan analisis perilaku konsumen, ada tiga hal yang dapat mempengaruhi perilaku konsumen antara lain: Faktor Eksternal, Faktor Internal/Psikologis, dan Faktor Jati Diri Pribadi yang kemudian dibagi menjadi beberapa indikator (Schiffman, 2007).

Tabel 1 Variabel Penelitian

\begin{tabular}{lllll}
\hline \multicolumn{1}{c}{ Dimensi } & \multicolumn{1}{c}{ Variabel } & \multicolumn{1}{c}{ Indikator } & \multicolumn{1}{c}{$\begin{array}{c}\text { No. } \\
\text { Pertanyaan }\end{array}$} & Cara Pengukuran \\
& 1. Eksternal & 1. Lingkungan & 1 & \\
& 2. Internal/ & 2. Kelompok Acuan & 5 & \\
Perilaku & Psikologis & 2. Motivasi & $21-30$ & \\
Konsumen & & 1. Pekerjaan & $4,9-10$ & Kuesioner \\
& 3. Jati Diri & 2. Ekonomi & 1 & \\
& Pribadi & 3. Gaya hidup & $2-3,6-8,11-$ & \\
& & & $14,16,19-20$ & \\
\hline
\end{tabular}

\section{Faktor Eksternal}

Lingkungan dan kelompok acuan merupakan bagian dari faktor eksternal seseorang yang dapat mempengaruhi perilaku konsumennya. Lingkungan disini adalah lingkungan sosial dan geografis berdasarkan sektor perusahaan (dan konsumen yang tidak bekerja) terhadap tingkat penggunaan jasa komunikasi. Kelompok acuan termasuk dalam kelompok referensi adalah keluarga, teman, rekan kerja, atau iklan untuk melihat apakah ada teman-teman atau anggota keluarga responden yang turut merekomendasikan ke responden lain.

\section{Faktor Internal/Psikologis}

Faktor internal berasal dari dalam diri konsumen, berupa motivasi dan persepsi. Faktor motivasi untuk melihat apakah yang melatarbelakangi seseorang atas penggunaan teknologi komunikasi dan faktor apa yang menyebabkan responden masih terus atau berhenti menggunakan jasa komunikasi. Faktor persepsi untuk melihat bagaimana pandangan responden terhadap teknologi VoIP saat ini dan setelah responden mengetahui ataupun memakai, apakah kemudian responden merasa puas dengan penggunaannya, apakah penggunaan VoIP masih perlu diperbaiki atau tidak, bagaimana pandangan mereka terhadap tarif yang dikenakan saatini, dan pendapat mereka bilamana adanya teknologi baru yang akan muncul setelah VoIP.

\section{Faktor Jati Diri Pribadi}

Faktor jati diri pribadi atau personal adalah bagian dari jati diri konsumen itu sendiri yang akan mempengaruhi perilaku konsumen meliputi pekerjaan,gaya hidup, dan ekonomi. 


\section{Populasi dan Sampel}

Dalam penelitian ini, populasi adalah para pengguna jasa komunikasi yang melakukan aktivitas sehari-hari di Jakarta. Sampel adalah bagian dari populasi yang memiliki karakteristik serupa dengan populasi dan digunakan untuk mewakili populasi penelitian. Perhitungan jumlah responden (sampel) menggunakan rumus Ukuran Sampel oleh Paguso, Garcia, dan Guerrero (Iqbal, 2002), yaitu:

$$
n=\frac{N}{1+N e^{2}}
$$

Keterangan:

$n=$ ukuran sampel

$N=$ ukuran populasi

$e=$ persen kelonggaran ketelitian karena kesalahan pengambilan sampel yang masih dapat ditolerir/diinginkan, misalnya $1 \%$

Dalam hal ini, penulis menggunakan ukuran populasi $(N)$ berupa jumlah penduduk Jakarta yang menggunakan jasa telekomunikasi melalui telepon pada tahun 2008, yaitu sebesar 2,377,175 orang dari 8,489,910 total penduduk Jakarta pada tahun 2008 (Suku Dinas Kependudukan dan Catatan Sipil Kotamadya, 2008). Persen kesalahan (e) yang digunakan adalah 5\%.

Melalui perhitungan berikut ini, $n=\frac{N}{1+N e^{2}}=\frac{2,377,175}{1+\left(2,377,175 \times 0.05^{2}\right)} \approx 400$, maka didapat jumlah responden $(n)$ yang diperlukan adalah sebesar 400 orang.

\section{HASIL DAN PEMBAHASAN}

\section{Hasil Pengolahan Data}

Hasil pengolahan data dibagi menjadi dua bagian utama. Bagian pertama, profil responden yang didapat, sedangkan bagian kedua akan menganalisis perilaku responden.

\section{Profil Responden}

Responden yang berpartisipasi dalam penelitian ini jika dilihat dari sektor pekerjaan maka dari 400 responden yang mengisi, mayoritas bekerja di sektor Pendidikan (30.5\%), dan 55\% tidak bekerja (kuesioner no. 1). Jika dilihat dari jenis kelamin maka dari 400 responden yang mengisi, $72.5 \%$ di antaranya adalah pria, $22.2 \%$ adalah wanita, dan $5.3 \%$ tidak menyebutkan jenis kelamin (informasi responden kuesioner). Jika dilihat dari usia maka responden yang mengisi kuesioner penelitian berkisar dari usia 17 sampai dengan 38 tahun. Mayoritas responden berusia 18 tahun sebesar 29.5\%, berusia 19 tahun sebesar 17.5\%, dan 21 tahun sebesar 10.2\% (informasi responden kuesioner). 
Tabel 2 Sektor Pekerjaan Responden

\begin{tabular}{lrr}
\hline \multicolumn{1}{c}{ Sektor } & Frekuensi & Persen \\
\hline Tidak Bekerja & 220 & 55.00 \\
Pendidikan & 122 & 30.50 \\
Perdagangan & 18 & 4.50 \\
Kesehatan & 10 & 2.50 \\
Manufaktur & 9 & 2.25 \\
Pertambangan & 5 & 1.25 \\
Properti & 5 & 1.25 \\
Industri Dasar & 3 & 0.75 \\
Keuangan & 2 & 0.50 \\
Konsumsi & 1 & 0.25 \\
Sosial & 1 & 0.25 \\
Investor & 1 & 0.25 \\
Konsultan & 1 & 0.25 \\
Wirausaha & 1 & 0.25 \\
Marketing & 1 & 0.25 \\
\hline \multicolumn{1}{c}{ Total } & $\mathbf{4 0 0}$ & $\mathbf{1 0 0 . 0 0}$ \\
\hline
\end{tabular}

Tabel 3Usia Responden

\begin{tabular}{crr}
\hline Usia & Frekuensi & Persen \\
\hline 17 & 30 & 7.50 \\
18 & 118 & 29.50 \\
19 & 70 & 17.50 \\
20 & 30 & 7.50 \\
21 & 41 & 10.25 \\
22 & 27 & 6.75 \\
23 & 9 & 2.25 \\
24 & 5 & 1.25 \\
25 & 9 & 2.25 \\
26 & 2 & 0.50 \\
27 & 2 & 0.50 \\
28 & 4 & 1.00 \\
29 & 4 & 1.00 \\
32 & 3 & 0.75 \\
33 & 1 & 0.25 \\
34 & 2 & 0.50 \\
36 & 2 & 0.50 \\
37 & 1 & 0.25 \\
38 & 1 & 0.25 \\
Tidak Mengisi & 39 & 9.75 \\
\hline Total & $\mathbf{4 0 0}$ & $\mathbf{1 0 0 . 0 0}$ \\
\hline
\end{tabular}

\section{Perilaku Responden}

Di Jakarta, sosialisasi kehadiran VoIP telah berhasil dilakukan dengan baik. Hal ini terlihat dari hasil penelitian dimana $100 \%$ responden menyatakan mereka mengetahui (aware) adanya teknologi VoIP (kuesioner no. 2). Selain itu, masyarakat juga mengetahui bahwa komputer/laptop dan handphone/PDA mendukung penggunaan Internet. Hal ini terlihat dari hasil penelitian bahwa100\% responden mengetahui bahwa handphone ataupun PDA mendukung penggunaan Internet selain komputer/laptop (kuesioner no. 3).

Dari 100\% responden tersebut, $97.5 \%$ responden pernah mencoba menggunakan VoIP (kuesioner no. 4) karena beberapa faktor dan atas rekomendasi beberapa pihak (kuesioner no. 5) seperti ditunjukkan pada gambar di bawah. Responden yang pernah menggunakan VoIP (97.5\%) ternyata tidak bertahan semua. Dari responden tersebut, 96\% masih terus menggunakan VoIP (kuesioner no. 9), dan 4\% responden memutuskan untuk berhenti (kuesioner no. 10) dikarenakan beberapa faktor seperti ditunjukkan pada gambar di bawah.

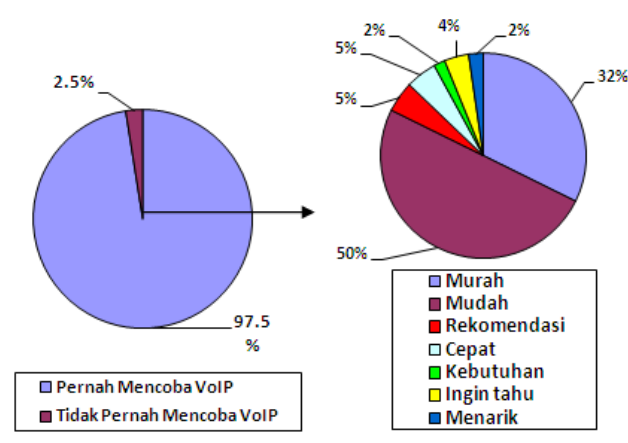

Gambar 3 Faktor Utama untuk Mencoba VoIP 


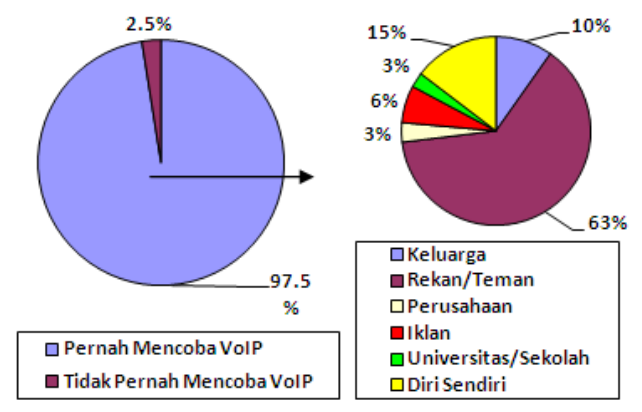

Gambar 4 Pihak yang Merekomendasikan Penggunaan VoIP
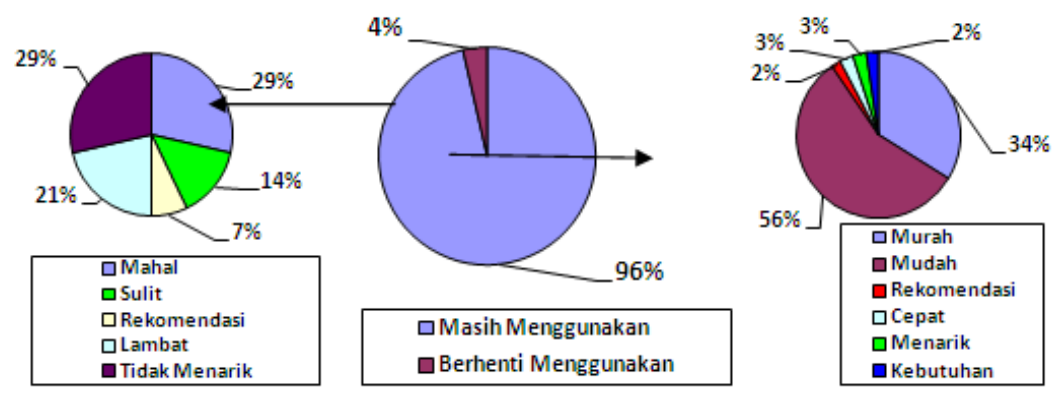

Gambar 5 Faktor yang Melanjutkan Penggunaan VoIP

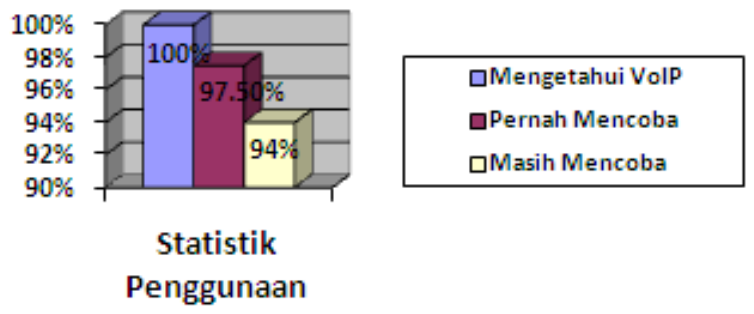

Gambar 6 Statistik Kelanjutan Penggunaan VoIP

\section{Analisis Hasil Penelitian}

Analisis hasil penelitian akan terbagi menjadi tiga bagian. Bagian pertama membahas mengenai gaya hidup responden terhadap VoIP, bagian kedua membahas mengenai gaya hidup responden terhadap komunikasi, dan bagian ketiga akan membahas gaya hidup responden terhadap Internet.

\section{Gaya Hidup Terhadap VoIP}

Penggunaan VoIP tentunya memerlukan baik perangkat keras maupun perangkat lunak. Penelitian menunjukkan bahwa dari responden yang pernah mencoba menggunakan VoIP (97.5\%), sebagian besar dari responden tersebut menggunakan komputer/laptop bersamaan dengan handphone/PDA (kuesioner no. 6). 

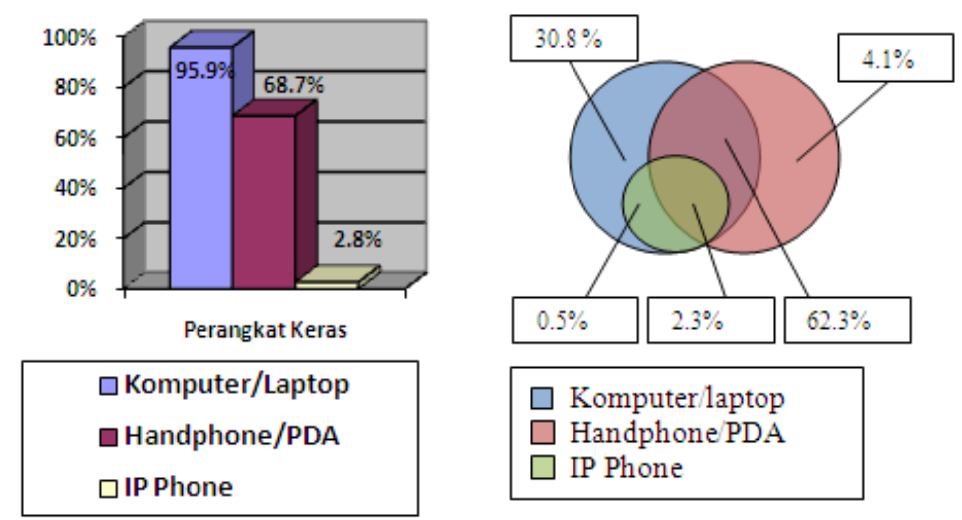

$\square$ Komputer/laptop

$\square$ Handphone PDA

$\square$ IP Phone

Gambar 7 Statistik Penggunaan Perangkat Keras

Penggunaan perangkat keras tidak terlepas dari penggunaan perangkat lunak. Penelitian menunjukkan bahwa dari responden yang pernah mencoba menggunakan VoIP (97.5\%), sebagian besar dari responden tersebut menggunakan YM!(kuesioner no. 7).

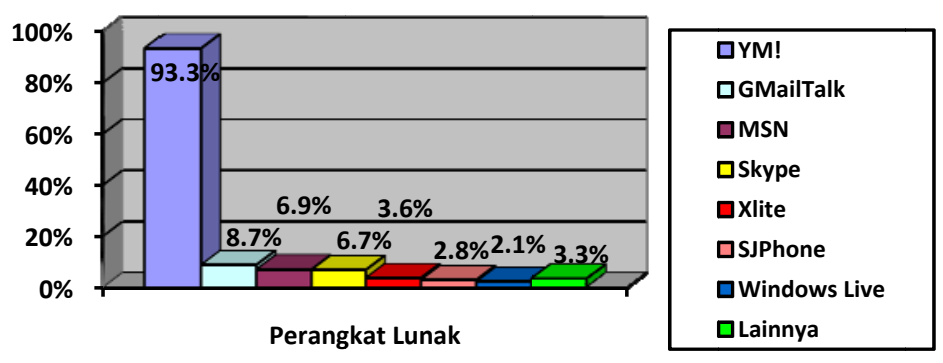

Gambar 8 Statistik Penggunaan Perangkat Lunak

Untuk mendapatkan perangkat lunak tersebut, penelitian menunjukkan bahwa dari responden yang pernah mencoba menggunakan VoIP (97.5\%), sebagian besar responden tersebut mendapatkan perangkat lunak dengan men-download dari Internet (kuesioner no. 8).

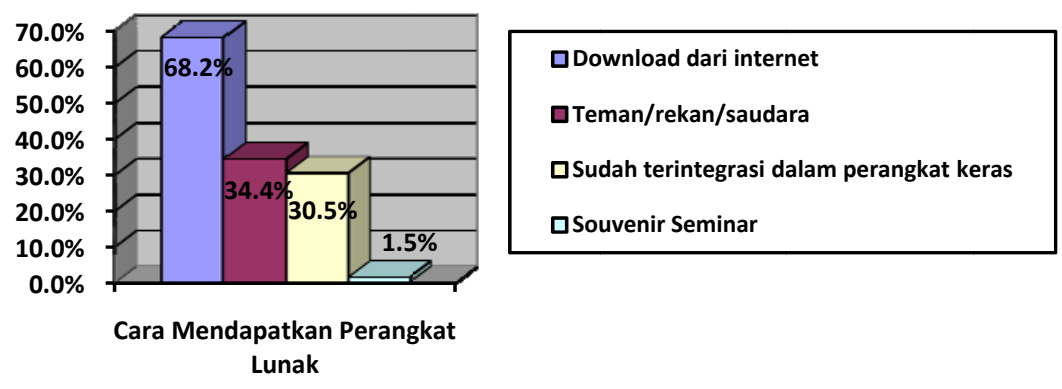

Gambar 9 Cara Mendapatkan Perangkat Lunak 
Penggunaan VoIP tentunya juga memiliki kendala baik dari segi perangkat, instalasi, pengoperasian, jaringan, ataupun kualitas suara. Penelitian (kuesioner no.21 dan no. 22) menunjukkan bahwa dari responden yang pernah mencoba menggunakan VoIP $(97.5 \%), 80 \%$ responden pernah mengalami kesulitan terhadap penggunaan VoIP, dan 20\% tidak mengalami kesulitan. Responden yang pernah mengalami kesulitan tersebut, sebagian besar mengatasinya dengan bertanya pada rekan/teman (41\%) atau bertanya pada service center/helpdesk (27\%).

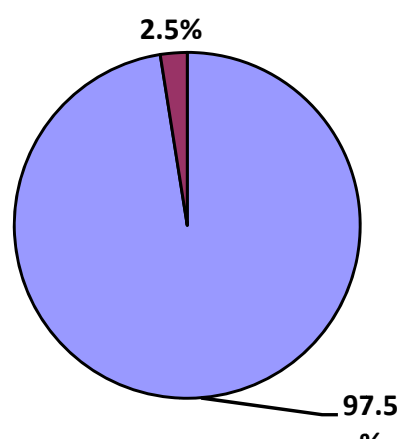

$\%$

Gambar 10 Responden yang Kesulitan Menggunakan VoIP

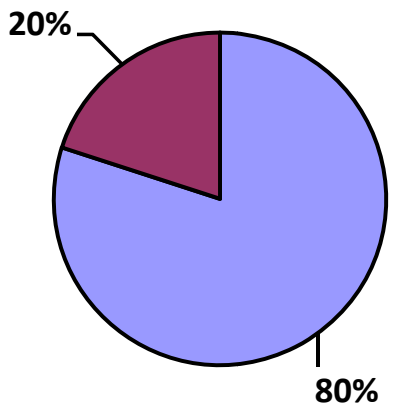

$80 \%$

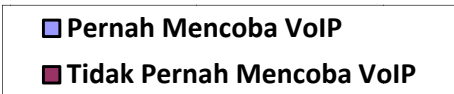
$\square$ Pernah Mencoba VolP
Mengalami Kesulitan
$\square$ Tidak Mengalami Kesulitan

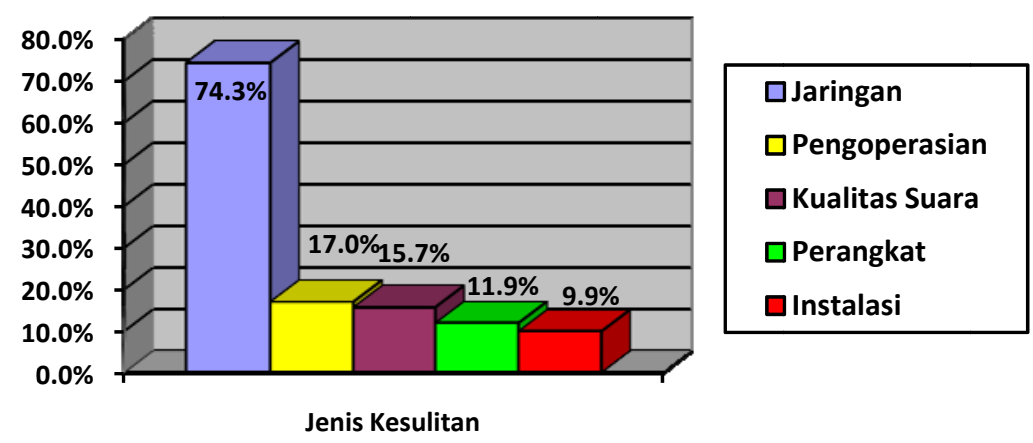

Gambar 11 Jenis Kesulitan yang Dialami

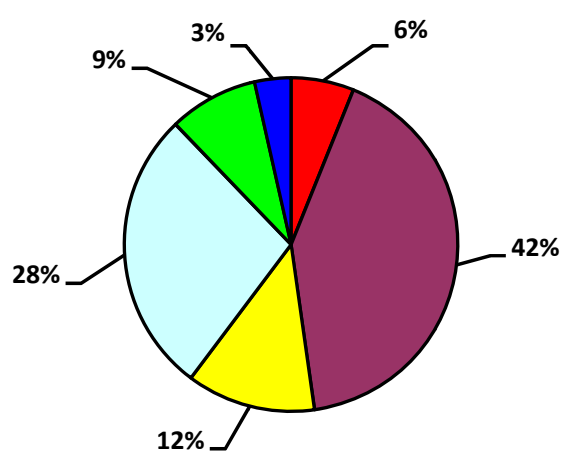

\begin{tabular}{|l|}
\hline Membeli/menggunakan \\
perangkat lain \\
$\square$ Bertanya pada rekan/teman \\
$\square$ Membaca tutorial/manual \\
penggunaan \\
$\square$ Bertanya pada service center \\
(helpdesk) \\
$\square$ Membetulkan sendiri \\
$\square$ Membiarkan
\end{tabular}

Gambar 12 Cara Mengatasi Kesulitan yang Dialami 


\section{Gaya Hidup Terhadap Komunikasi}

Penggunaan VoIP didasarkan pada kebutuhan komunikasi melalui Internet. Selain melalui Internet, responden juga menggunakan operator lain untuk memenuhi kebutuhan komunikasi. Hasil penelitian menunjukkan persentase responden yang menggunakan jasa komunikasi pada jaringan GSM, PSTN, dan CDMA (kuesioner no. 11, 12, dan 13).

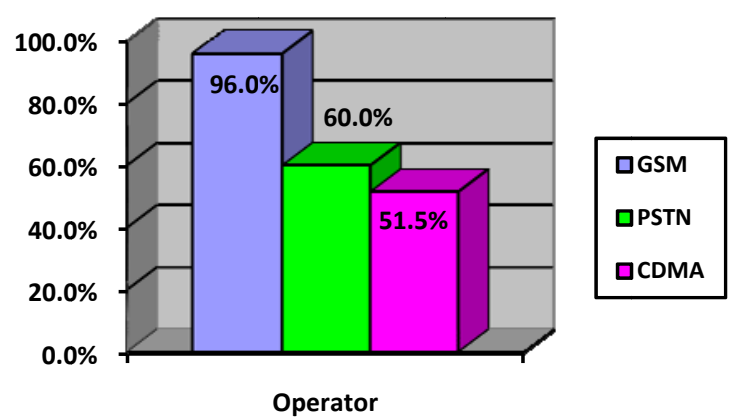

Gambar 13 Pengguna GSM, PSTN, dan CDM
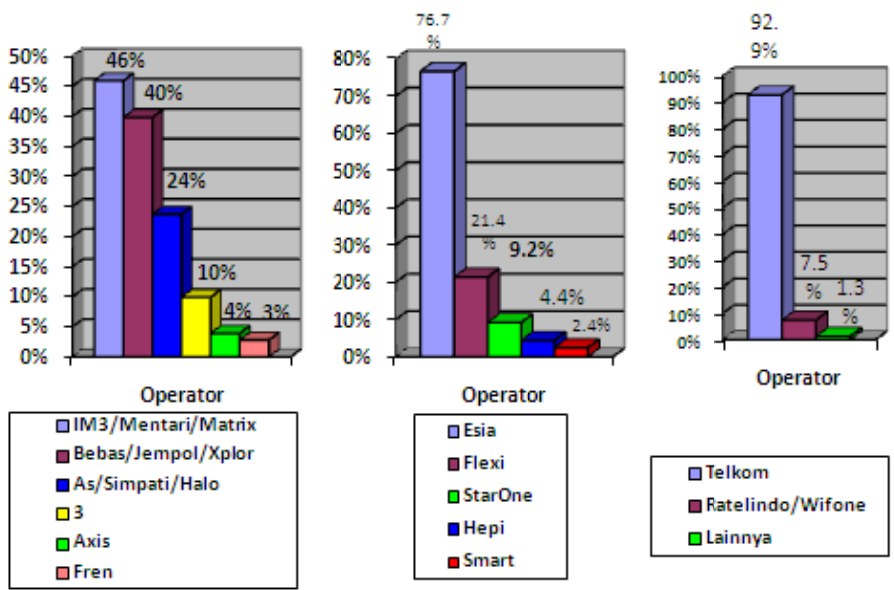

Gambar 14 Distribusi Pengguna (a) GSM, (b) CDMA, dan (c) PSTN

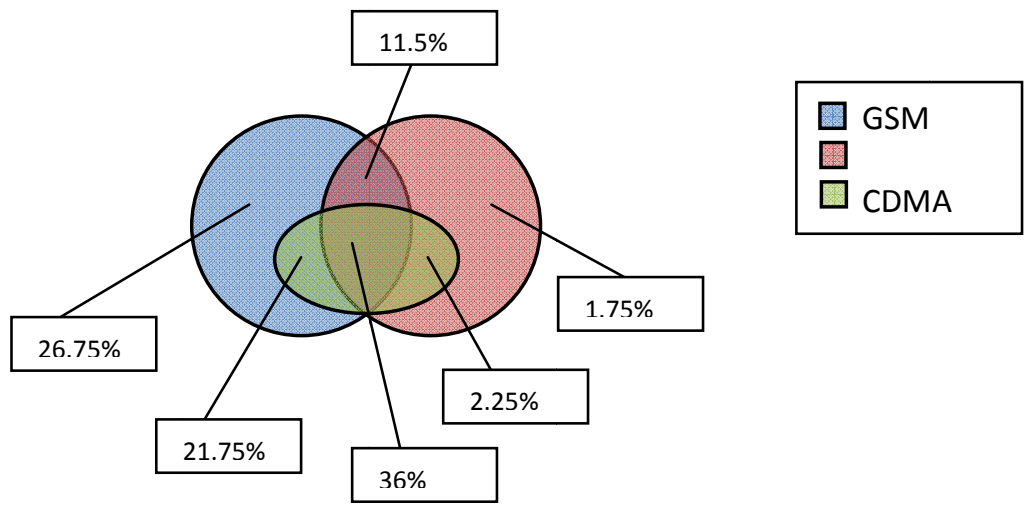

Gambar 15 Distribusi Pengguna GSM, CDMA, dan PSTN Keseluruhan 
Aktivitas komunikasi pada komputer ataupun handphone meliput banyak hal, seperti SMS, MMS, telepon, video conference (video call), ataupun chatting. Penelitian (kuesioner no. 20) menunjukkan bahwa aktivitas yang sering dilakukan adalah SMS (83.3\%), telepon (71.5\%), dan chatting (59.5\%).

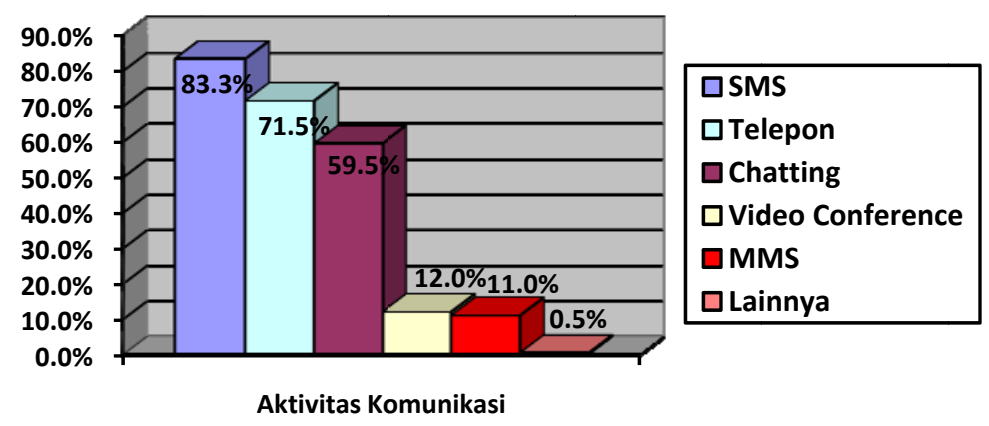

Gambar 16 Aktivitas Komunikasi yang Sering Dilakukan

Adapun jumlah rata-rata responden melakukan panggilan dalam 1 hari dan lama per panggilan ditampilkan dalam tabel berikut (kuesioner no. 16).

Tabel 4 Jumlah dan Lama Aktivitas Menelepon

\begin{tabular}{|c|c|c|c|c|c|c|c|}
\hline \multirow[b]{2}{*}{ Jenis } & \multirow{2}{*}{\multicolumn{2}{|c|}{$\begin{array}{l}\text { Jumlah rata-rata } \\
\text { responden melakukan } \\
\text { panggilan dalam } 1 \text { hari }\end{array}$}} & \multicolumn{5}{|c|}{ Lama rata-rata responden dalam melakukan 1 panggilan (dalam menit) } \\
\hline & & & $<1$ & $\begin{array}{c}>=1 \mathrm{~s} / \mathrm{d} \\
\quad<10\end{array}$ & $\begin{array}{c}>=10 \mathrm{~s} / \mathrm{d} \\
\quad<30\end{array}$ & $\begin{array}{c}>=30 \mathrm{~s} / \mathrm{d} \\
<60\end{array}$ & $>=60$ \\
\hline \multirow{3}{*}{ Lokal } & 0 & $4.8 \%$ & - & - & - & - & - \\
\hline & $<5$ & $69.0 \%$ & $17.0 \%$ & $35.8 \%$ & $9.0 \%$ & $3.0 \%$ & $4.2 \%$ \\
\hline & $>=5$ & $26.2 \%$ & $1.3 \%$ & $10.7 \%$ & $7.3 \%$ & $4.0 \%$ & $3.0 \%$ \\
\hline \multirow{3}{*}{$\begin{array}{l}\text { Interlokal } \\
\text { (SLJJ) }\end{array}$} & 0 & $58.2 \%$ & - & - & - & - & - \\
\hline & $<5$ & $34.8 \%$ & $6.7 \%$ & $18.7 \%$ & $5.5 \%$ & $1.3 \%$ & $2.5 \%$ \\
\hline & $>=5$ & $7.0 \%$ & $0.8 \%$ & $2.5 \%$ & $1.3 \%$ & $1.7 \%$ & $0.7 \%$ \\
\hline \multirow{3}{*}{$\begin{array}{l}\text { Internasional } \\
\text { (SLI) }\end{array}$} & 0 & $91.5 \%$ & - & - & - & - & - \\
\hline & $<5$ & $7.3 \%$ & $2.0 \%$ & $2.7 \%$ & $1.8 \%$ & $0.5 \%$ & $0.3 \%$ \\
\hline & $>=5$ & $1.2 \%$ & $0.0 \%$ & $0.0 \%$ & $0.3 \%$ & $0.3 \%$ & $0.7 \%$ \\
\hline
\end{tabular}

Adapun mayoritas biaya rata-rata pemakaian telekomunikasi (tidak termasuk biaya Internet) didapat dari hasil penelitian (kuesioner no. 17) yaitu sebesar Rp. 50,000 - Rp. 100,000 (40.2\%) dan Rp. 100,001 - Rp. 500,000 (31.8\%).

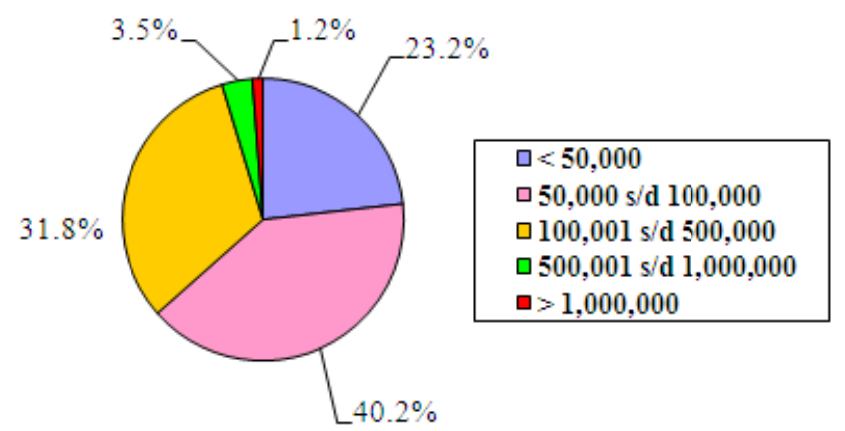

Gambar 17 Rata-Rata Biaya Pemakaian Telekomunikasi 


\section{Gaya Hidup Terhadap Internet}

Berdasarkan hasil penelitian (kuesioner no. 14), 53.5\% responden menggunakan Internet melalui operator GSM, 23.8\% responden menggunakan operator PSTN, 21\% responden menggunakan ISP khusus yaitu Fastnet (First Media), dan 8.8\% menggunakan operator CDMA.

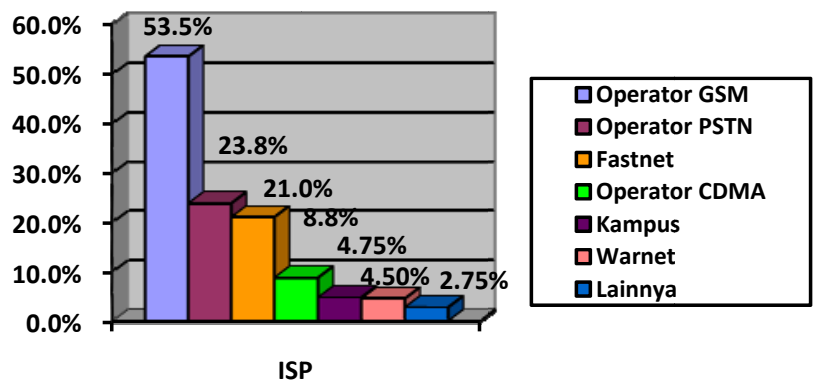

Gambar 18 ISP yang Digunakan

Penelitian (kuesioner no. 15) menunjukkan bahwa 48.2\% responden terhubung dengan Internet kurang dari 8 jam sehari, 31.6\% responden terhubung dengan Internet antara 8 sampai dengan 12 jam sehari, $13.2 \%$ responden terhubung dengan Internet lebih dari 12 jam tetapi kurang dari 24 jam sehari, dan $7 \%$ responden terhubung dengan Internet 24 jam sehari.

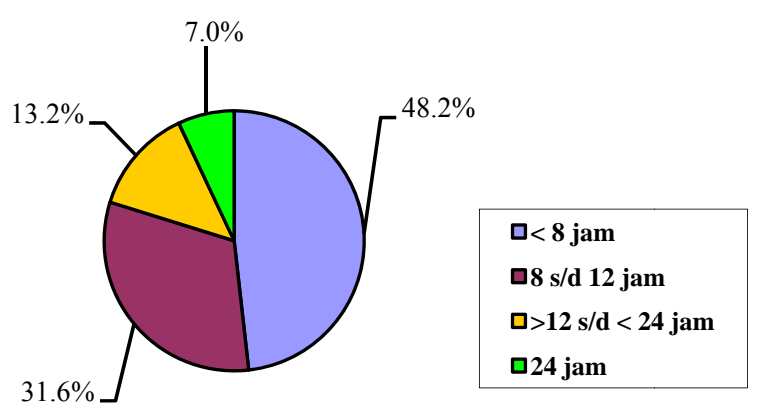

Gambar 19 Lama Penggunaan Internet per Hari

Perhitungan tarif yang dikenakan pada pengguna Internet bergantung pada operator penyedia Internet yang digunakan (Berkeley Lab, 2008). Hasil penelitian (kuesioner no. 19) menunjukkan bahwa $46.2 \%$ responden menggunakan Internet dengan perhitungan tarif unlimited, 19.8\% responden dengan perhitungan tarif per kilobyte(volume based), 19.2\% responden dengan perhitungan per waktu (time based), dan 15\% ditanggung pihak lain, seperti kantor (Purwanto, 2008). 
Tabel 5 Daftar ISP Pada Operator GSM, CDMA, dan PSTN (Tabloid PULSA, 2008)

\begin{tabular}{cccr}
\hline Jaringan & Operator & \multicolumn{2}{c}{ Tarif } \\
\hline \multirow{4}{*}{ GSM } & 3 & Rp. & $10 / \mathrm{kb}$ \\
& IM3 & Rp. & $1 / \mathrm{kb}$ \\
& Matrix & Rp. & $1 / \mathrm{kb}$ \\
& Fren & Rp. & $1 / \mathrm{kb}$ \\
& Axis & Rp. & $6 / \mathrm{kb}$ \\
& As & Rp. & $0.7 / \mathrm{kb}$ \\
& Simpati & Rp. & $1 / \mathrm{kb}$ \\
& Halo & Rp. & $5 / \mathrm{kb}$ \\
& Bebas & Rp. & $8 / \mathrm{kb}$ \\
& Jempol & Rp. & $10 / \mathrm{kb}$ \\
& Xplor & Rp. & $10 / \mathrm{kb}$ \\
& Esia & Rp. & $10 / \mathrm{kb}$ \\
\hline \multirow{4}{*}{ CDMA } & StarOne & Rp. & $250 / \mathrm{mnt}$ \\
& Hepi & Rp. & $1 / \mathrm{kb}$ \\
& Smart & Rp. & $1 / \mathrm{kb}$ \\
& Flexi & Rp. & $2.2 / \mathrm{kb}$ \\
& TelkomNet & Rp. & $5 / \mathrm{kb}$ \\
\hline \multirow{3}{*}{ PSTN } & Speedy & Rp. & $165 / \mathrm{mnt}$ \\
& & & $200.000 / \mathrm{bln}$ \\
\hline & &
\end{tabular}

Tabel 6 Daftar Beberapa ISP Khusus di Jakarta

\begin{tabular}{lccr}
\multicolumn{1}{c}{ Nama Provider } & Koneksi & Tarif & Quota \\
\hline Indosat 3.5G & Wireless & Rp. 160.000/bln & 700MB \\
XL 3.5G & Wireless & Rp. 99.000/bln & 250MB \\
Telkom Flash & Wireless & Rp. 125.000/bln & 500MB \\
Fastnet & Kabel & Rp. 99.000/bln & Unlimited \\
NetZap & Wireless & Rp. 275.000/bln & Unlimited \\
\hline
\end{tabular}

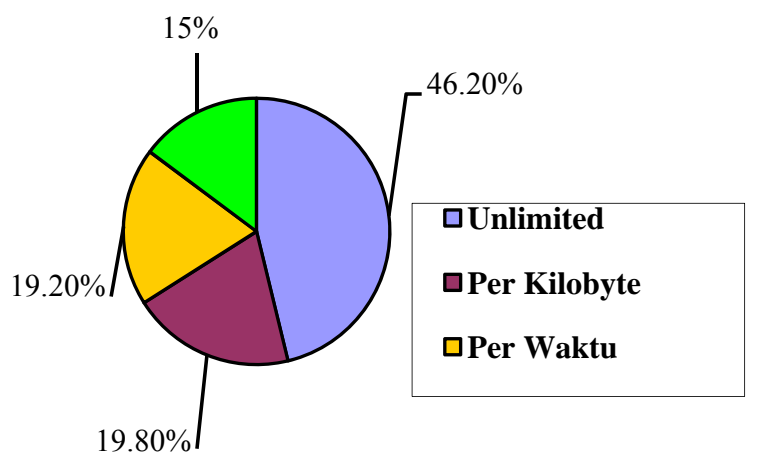

Gambar 20 Cara Perhitungan Tarif Penggunaan Internet 
Adapun mayoritas biaya rata-rata pemakaian Internet didapat dari hasil penelitian (kuesioner no. 18) yaitu sebesar Rp100.001 - Rp500.000 (54.8\%) dan Rp50.000 - Rp. 100.000 (17.2\%).

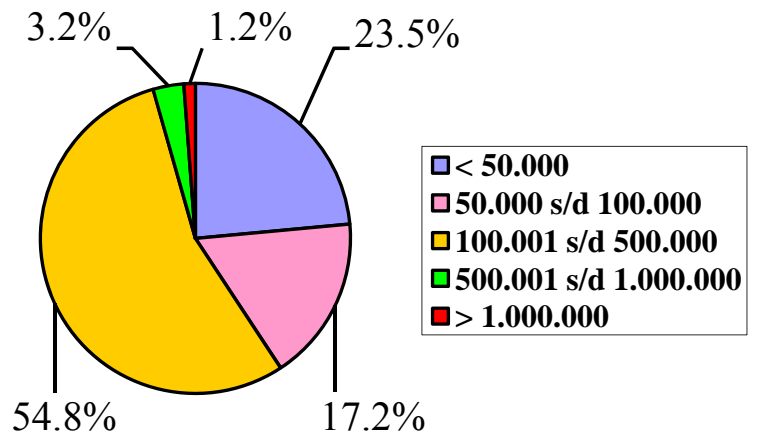

Gambar 21 Rata-Rata Biaya Pemakaian Internet

\section{Analisis Biaya}

Bagian analisis biaya ini merupakan pembahasan mengenai perbandingan tarif baik pada VoIP, operator GSM, CDMA, dan PSTN. Hasil dari pembahasan ini akan menjawab permasalahan penelitian. Tabel berikut menampilkan daftar tarif termurah dengan beberapa kondisi tertentu pada semua operator GSM dan CDMA yang ada di Indonesia dan operator PSTN yang ada di Jakarta (per November 2008).

Tabel 7 Tarif Percakapan Operator GSM

\begin{tabular}{lcccccc}
\hline \multicolumn{7}{c}{ Tarif Percakapan } \\
\hline $\begin{array}{l}\text { Tujuan } \\
\text { Sesama }\end{array}$ & Lokal & Operator & Interlokal & Operator & Internasional & Operator \\
$\begin{array}{l}\text { Operator } \\
\begin{array}{l}\text { Operator } \\
\text { Lain }\end{array}\end{array}$ & $60^{1}$ & Axis & $60^{1}$ & Axis & $354^{2}$ & Fren \\
$\begin{array}{l}\text { Lainnya } \\
\text { (PSTN) }\end{array}$ & $300^{3}$ & Mentari & $300^{4}$ & Mentari & $900^{5}$ & - \\
\hline
\end{tabular}

Keterangan:

1 Hari Senin sampai Jumat

2 Ke Negara Brunai, Canada, Guam, Hong Kong, China, Macao, Malaysia, Singapore, Thailand, dan USA

3 Pukul 23:00 - 16:59

4 Pukul 23:00-04:59

5 Sesuai Tarif SLI 001/008

Tabel 8 Tarif Percakapan Operator CDMA

\begin{tabular}{|c|c|c|c|c|c|c|}
\hline \multicolumn{7}{|c|}{ Tarif Percakapan Operator CDMA (dalam Rupiah per menit) } \\
\hline Tujuan & Lokal & Operator & Interlokal & Operator & Internasional & Operator \\
\hline $\begin{array}{l}\text { Sesama } \\
\text { Operator }\end{array}$ & $30^{1}$ & Hepi & $30^{1}$ & Hepi & $900^{2}$ & StarOne \\
\hline $\begin{array}{l}\text { Operator } \\
\text { Lain }\end{array}$ & 500 & Hepi & 800 & Esia & $900^{2}$ & StarOne \\
\hline $\begin{array}{l}\text { Lainnya } \\
\text { (PSTN) }\end{array}$ & 150 & Flexi & 1000 & Esia & $900^{2}$ & StarOne \\
\hline
\end{tabular}




\section{Keterangan:}

1 Selama Masa Promosi

2 Sesuai Tarif SLI 001/008

Tabel 9 Tarif Percakapan Operator PSTN

\begin{tabular}{|c|c|c|c|c|c|c|}
\hline \multicolumn{7}{|c|}{ Tarif Percakapan Operator PSTN (dalam Rupiah per menit) } \\
\hline Tujuan & Lokal & Operator & Interlokal & Operator & Internasional & Operator \\
\hline $\begin{array}{l}\text { Sesama } \\
\text { Operator }\end{array}$ & $83^{1}$ & Telkom & 100 & Wifone & $770^{2}$ & Telkom \\
\hline $\begin{array}{l}\text { Operator } \\
\text { Lain } \\
\text { (CDMA) }\end{array}$ & $122^{1}$ & Telkom & $320^{3}$ & Telkom & $770^{2}$ & Telkom \\
\hline $\begin{array}{l}\text { Lainnya } \\
\text { (GSM) }\end{array}$ & $167^{4}$ & Telkom & $600^{5}$ & Telkom & $770^{2}$ & Telkom \\
\hline
\end{tabular}

\section{Keterangan:}

1 Pukul 18:00 - 08:00

2 Ke Negara Group I Telkom

3 Pukul 23:00 - 06:00, Rp. 32 / 6 detik

4 Pukul 09:00-15:00, Rp. 250/ 1.5 menit

5 Pukul 23:00-06:00, Rp. 200 / 20 detik

Penggunaan voice per kanal (half-duplex) membutuhkan 6 kilobytes per detik atau setara dengan 0.73 kilobytes per detik. Untuk penggunaan full-duplex, diperlukan 0.73 × $2=1.46$ kilobytes per detik. Penggunaan selama satu menit memerlukan 1.46 x $60=87.6$ kilobytes per menit. Berdasarkan Tabel 5, mayoritas operator memasang tarif GPRS sebesar Rp. 1/kilobytes, sehingga perhitungan tarif GPRS mengacu kepada tarif tersebut. Hal ini diperkuat dari Gambar 13 yang menunjukkan bahwa 96\% menggunakan GSM, di mana pada Gambar 14 mayoritas pengguna GSM menggunakan Indosat (46\%) dengan tarif GPRS Rp. 1/kilobytes. Dari acuan tersebut diperoleh hasil perhitungan penggunaan GPRS untuk kebutuhan voice memerlukan biaya Rp. 1 x $87.6=\mathrm{Rp}$. 87.6/menit. Adapun persentase perbandingan biaya dapat dilihat di tabel di bawah ini.

Tabel 10 Persentase Perbandingan Tarif

\begin{tabular}{lccccccccc}
\hline \multicolumn{9}{c}{ Tarif Percakapan VoIP (Rp. 87.6/menit) } \\
\hline \multirow{2}{*}{ Tujuan } & \multicolumn{3}{c}{ Lokal (dalam \%) } & \multicolumn{3}{c}{ Interlokal (dalam \%) } & \multicolumn{2}{c}{ Internasional (dalam \%) } \\
\cline { 2 - 11 } & GSM & CDMA & PSTN & GSM & CDMA & PSTN & GSM & CDMA & PSTN \\
\hline Sesama & -46.0 & -192 & -5.5 & -46.0 & -192 & 12.4 & 75.3 & 90.3 & 88.6 \\
$\begin{array}{l}\text { Operator } \\
\text { Operator }\end{array}$ & 70.8 & 82.5 & 28.2 & 70.8 & 89.1 & 72.6 & 90.3 & 90.3 & 88.6 \\
Lain & 78.0 & 41.6 & 47.5 & 91.2 & 91.2 & 85.4 & 90.3 & 90.3 & 88.6 \\
Lainnya & & & & & & & & & \\
\hline
\end{tabular}

\section{Keterangan:}

Perhitungan merupakan persentase dari selisih harga tarif terhadap harga operator Nilai positif menunjukkan besar persentase biaya yang dapat ditekan bila menggunakan VoIP 
Dari tabel di atas diperoleh hasil analisis: (1) Penggunaan VoIP untuk area lokal dan interlokal tidak menguntungkan bila dibandingkan dengan penggunaan sesama operator GSM/CDMA/PSTN (khusus area interlokal dengan sesama PSTN, menggunakan VoIP lebih menguntungkan 12.4\%). (2) Penggunaan VoIP untuk area lokal lebih menguntungkan sekitar $40 \%-80 \%$ bila dibandingkan dengan operator GSM/CDMA dan lebih menguntungkan sekitar 30\%-50\% bila dibandingkan dengan operator PSTN saat lintas operator. (3) Pengunaan VoIP untuk area interlokal lebih menguntungkan sekitar $70 \%$ - 90\% bila dibandingkan dengan operator GSM/CDMA/PSTN saat lintas operator. (4) Pengunaan VoIP untuk area internasional lebih menguntungkan sekitar 75\% - 90\% bila dibandingkan dengan operator GSM/CDMA/PSTN baik sesama operator ataupun lintas operator

\section{Analisis Korelasi (Terhadap Model Analisis Penelitian)}

Bagian analisis ini akan menguji hipotesis mengenai korelasi antara perilaku konsumen dengan penggunaan VoIP. Faktor-faktor yang mempengaruhi perilaku konsumen adalah Faktor Eksternal, Faktor Pribadi, dan Faktor Internal. Masing-masing faktor ini akan diuji tingkat korelasinya terhadap keputusan konsumen menggunakan VoIP. Pengujian korelasi menggunakan tes kebebasan $\chi^{2}$ ( $\chi^{2}$ test of independence), yaitu tes yang digunakan untuk menguji tingkat kebebasan atau hubungan terhadap dua kategori variabel (Levine, 2005). Adapun persamaan yang digunakan:

$$
\chi^{2}=\sum_{\text {allcells }} \frac{\left(f_{0}-f_{e}\right)^{2}}{f_{e}}
$$

Hipotesis tes kebebasan meliputi:

$\mathrm{H}_{0}$ : Dua kategori variabel adalah saling bebas (tidak ada hubungan)

$\mathrm{H}_{1}$ : Dua kategori variabel adalah saling bergantung (ada hubungan)

Hasil pengujian akan menolak $\mathrm{H}_{0}$ jika pada tingkat keberartian (level of significance) sebesar $\alpha$ dan hasil perhitungan $\chi^{2}$ lebih besar daripada $\chi_{U}^{2}$ dengan tingkat kebebasan (degree of freedom) $\operatorname{sebesar}(r-1)(c-1)$.

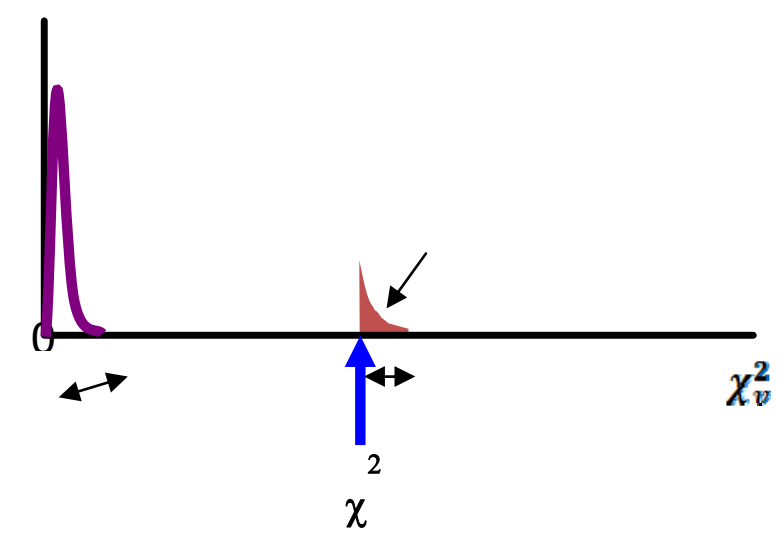

Gambar 22 Area Penerimaan dan Penolakan Pada Tes Kebebasan $\chi^{2}$

Pengujian Faktor Eksternal menggunakan variabel hasil penelitian berupa pihak yang merekomendasikan responden (kuesioner no. 5) dengan variabel penggunaan VoIP (kuesioner no. 7) seperti ditunjukkan pada tabel berikut. 
Tabel 11 Frekuensi Observasi $\left(\boldsymbol{f}_{\mathbf{0}}\right)$ Faktor Eksternal Responden

\begin{tabular}{llrrrrrrrr}
\hline \multirow{2}{*}{ Menggunakan VoIP } & \multicolumn{7}{c}{ Perangkat Lunak Yang Dipakai } & \multirow{2}{*}{$\Sigma$} \\
\cline { 2 - 8 } & Keluarga & 0 & 0 & 2 & 1 & 35 & 1 & 6 & 45 \\
Rekix & Idefisk & $\begin{array}{c}\text { SJ } \\
\text { Phone }\end{array}$ & Xlite & $\begin{array}{c}\text { YM } \\
\text { Remendasi }\end{array}$ & $\begin{array}{c}\text { Gmail } \\
\text { Talk }\end{array}$ & Lainnya & \\
Mencoba & Rekan & 0 & 1 & 5 & 6 & 233 & 18 & 45 & 308 \\
Internet Untuk & Perusahaan & 0 & 0 & 1 & 2 & 12 & 0 & 0 & 15 \\
Komunikasi & Iklan & 1 & 0 & 1 & 2 & 24 & 3 & 6 & 37 \\
& Lainnya & 0 & 2 & 1 & 2 & 60 & 12 & 17 & 94 \\
\hline \multicolumn{1}{c}{$\Sigma$} & 1 & 3 & 10 & 13 & 364 & 34 & 74 & 499 \\
\hline
\end{tabular}

Tabel 12 Frekuensi Harapan $\left(\boldsymbol{f}_{\boldsymbol{e}}\right)$ Faktor Eksternal Responden

\begin{tabular}{|c|c|c|c|c|c|c|c|c|}
\hline \multirow{2}{*}{\multicolumn{2}{|c|}{ Menggunakan VoIP }} & \multicolumn{7}{|c|}{ Perangkat Lunak Yang Dipakai } \\
\hline & & Cubix & Idefisk & $\begin{array}{c}\text { SJ } \\
\text { Phone }\end{array}$ & Xlite & YM! & $\begin{array}{c}\text { Gmail } \\
\text { Talk }\end{array}$ & Lainnya \\
\hline \multirow{5}{*}{$\begin{array}{l}\text { Rekomendasi } \\
\text { Mencoba } \\
\text { Internet Untuk } \\
\text { Komunikasi }\end{array}$} & Keluarga & 0.09 & 0.27 & 0.90 & 1.17 & 32.83 & 3.07 & 6.67 \\
\hline & $\begin{array}{l}\text { Rekan/ } \\
\text { Teman }\end{array}$ & 0.62 & 1.85 & 6.17 & 8.02 & 224.67 & 20.99 & 45.68 \\
\hline & Perusahaan & 0.03 & 0.09 & 0.30 & 0.39 & 10.94 & 1.02 & 2.22 \\
\hline & Iklan & 0.07 & 0.22 & 0.74 & 0.96 & 26.99 & 2.52 & 5.49 \\
\hline & Lainnya & 0.19 & 0.57 & 1.88 & 2.45 & 68.57 & 6.40 & 13.94 \\
\hline
\end{tabular}

Frekuensi Harapan $\left(f_{e}\right)$ didapat dari $f_{e}=\frac{\text { row total x column total }}{n}$

Tabel 13 Perhitungan $\chi^{2}$ Faktor Eksternal Responden

\begin{tabular}{|c|c|c|c|c|c|c|c|c|}
\hline \multirow{2}{*}{\multicolumn{2}{|c|}{ Menggunakan VoIP }} & \multicolumn{7}{|c|}{ Perangkat Lunak Yang Dipakai } \\
\hline & & Cubix & Idefisk & $\begin{array}{c}\text { SJ } \\
\text { Phone }\end{array}$ & Xlite & YM! & $\begin{array}{c}\text { Gmail } \\
\text { Talk }\end{array}$ & Lainnya \\
\hline \multirow{5}{*}{$\begin{array}{l}\text { Rekomendasi } \\
\text { Mencoba } \\
\text { Internet Untuk } \\
\text { Komunikasi }\end{array}$} & Keluarga & 0.09 & 0.27 & 1.34 & 0.03 & 0.14 & 1.39 & 0.07 \\
\hline & $\begin{array}{l}\text { Rekan/ } \\
\text { Teman }\end{array}$ & 0.62 & 0.39 & 0.22 & 0.51 & 0.31 & 0.42 & 0.01 \\
\hline & $\begin{array}{l}\text { Perusahaa } \\
\mathrm{n}\end{array}$ & 0.03 & 0.09 & 1.63 & 6.63 & 0.10 & 1.02 & 2.22 \\
\hline & Iklan & 11.56 & 0.22 & 0.09 & 1.11 & 0.33 & 0.09 & 0.05 \\
\hline & Lainnya & 0.19 & 3.64 & 0.41 & 0.08 & 1.07 & 4.89 & 0.67 \\
\hline
\end{tabular}

Melalui tingkat kebebasan Faktor Eksternal adalah $(\mathrm{r}-1) \times(\mathrm{c}-1)=(5-1) \times(7-1)=4 \times 6=$ 24 dan tingkat keberartian sebesar $\alpha=0.05$, maka didapat $\chi_{24}^{2}=36.415$. Dari hasil perhitungan tersebut didapat bahwa $\chi^{2}>\chi_{24}^{2}$, sehingga $\mathrm{H}_{0}$ ditolak atau $\mathrm{H}_{1}$ diterima. Kesimpulan yang diperoleh adalah adanya saling kebergantungan antara variabel Faktor Eksternal terhadap variabel keputusan konsumen dalam menggunakan VoIP.

Pengujian Faktor Internal menggunakan variabel hasil penelitian berupa faktor utama kelanjutan responden (kuesioner no. 9) dengan variabel penggunaan VoIP (kuesioner no. 7) seperti ditunjukkan pada tabel berikut. 
Tabel 14 Frekuensi Observasi $\left(f_{0}\right)$ Faktor Internal Responden

\begin{tabular}{|c|c|c|c|c|c|c|c|c|c|}
\hline \multirow{2}{*}{\multicolumn{2}{|c|}{ Menggunakan VoIP }} & \multicolumn{7}{|c|}{ Perangkat Lunak Yang Dipakai } & \multirow[b]{2}{*}{$\Sigma$} \\
\hline & & \multirow{2}{*}{$\begin{array}{r}\text { Cubix } \\
0\end{array}$} & \multirow{2}{*}{$\begin{array}{r}\text { Idefisk } \\
1\end{array}$} & \multirow{2}{*}{$\begin{array}{c}\begin{array}{c}\text { SJ } \\
\text { Phone }\end{array} \\
4\end{array}$} & \multirow{2}{*}{$\begin{array}{r}\text { Xlite } \\
5\end{array}$} & \multirow{2}{*}{$\begin{array}{r}\text { YM! } \\
121\end{array}$} & \multirow{2}{*}{$\begin{array}{c}\text { Gmail } \\
\text { Talk }\end{array}$} & Lainnya & \\
\hline \multirow{5}{*}{$\begin{array}{l}\text { Faktor Masih } \\
\text { Menggunakan } \\
\text { Internet }\end{array}$} & Murah & & & & & & & 24 & 171 \\
\hline & Mudah & 1 & 2 & 5 & 7 & 197 & 16 & 42 & 270 \\
\hline & Rekomendasi & 0 & 0 & 0 & 0 & 7 & 1 & 0 & 8 \\
\hline & Lainnya & 0 & 0 & 0 & 0 & 26 & 1 & 6 & 33 \\
\hline & $\Sigma$ & 1 & 3 & 9 & 12 & 351 & 34 & 72 & 482 \\
\hline
\end{tabular}

Tabel 15 Frekuensi Harapan $\left(\boldsymbol{f}_{\boldsymbol{e}}\right)$ Faktor Internal Responden

\begin{tabular}{llrrrrrrr}
\hline & & \multicolumn{7}{c}{ Perangkat Lunak Yang Dipakai } \\
\cline { 3 - 9 } \multicolumn{1}{c}{ Menggunakan VoIP } & Cubix & Idefisk & $\begin{array}{c}\text { SJ } \\
\text { Phone }\end{array}$ & Xlite & YM! & $\begin{array}{r}\text { Gmail } \\
\text { Talk }\end{array}$ & Lainnya \\
& & & & & & & \\
& Murah & 0.35 & 1.06 & 3.19 & 4.26 & 124.52 & 12.06 & 25.54 \\
Faktor Masih & Mudah & 0.56 & 1.68 & 5.04 & 6.72 & 196.62 & 19.05 & 40.33 \\
Menggunakan & Rekomendasi & 0.02 & 0.05 & 0.15 & 0.20 & 5.83 & 0.56 & 1.20 \\
Internet & Lainnya & 0.07 & 0.21 & 0.62 & 0.82 & 24.03 & 2.33 & 4.93 \\
\hline
\end{tabular}

Frekuensi Harapan $\left(f_{e}\right)$ didapat dari $f_{e}=\frac{\text { row total x column total }}{n}$

Tabel 16 Perhitungan $\chi^{2}$ Faktor Internal Responden

\begin{tabular}{|c|c|c|c|c|c|c|c|c|}
\hline \multirow{2}{*}{\multicolumn{2}{|c|}{ Menggunakan VoIP }} & \multicolumn{7}{|c|}{ Perangkat Lunak Yang Dipakai } \\
\hline & & \multirow{2}{*}{$\begin{array}{r}\text { Cubix } \\
0.35\end{array}$} & \multirow{2}{*}{$\begin{array}{r}\text { Idefisk } \\
0.00\end{array}$} & \multirow{2}{*}{$\begin{array}{c}\begin{array}{c}\text { SJ } \\
\text { Phone }\end{array} \\
0.20\end{array}$} & \multirow{2}{*}{$\begin{array}{r}\text { Xlite } \\
0.13\end{array}$} & \multirow{2}{*}{$\begin{array}{c}\text { YM! } \\
0.10\end{array}$} & \multirow{2}{*}{$\begin{array}{c}\begin{array}{c}\text { Gmail } \\
\text { Talk }\end{array} \\
1.29\end{array}$} & \multirow{2}{*}{$\begin{array}{r}\text { Lainnya } \\
0.09\end{array}$} \\
\hline \multirow{4}{*}{$\begin{array}{l}\text { Faktor Masih } \\
\text { Menggunakan } \\
\text { Internet }\end{array}$} & Murah & & & & & & & \\
\hline & Mudah & 0.35 & 0.06 & 0.00 & 0.01 & 0.00 & 0.49 & 0.07 \\
\hline & Rekomendasi & 0.02 & 0.05 & 0.15 & 0.20 & 0.24 & 0.34 & 1.20 \\
\hline & Lainnya & 0.07 & 0.21 & 0.62 & 0.82 & 0.16 & 0.76 & 0.23 \\
\hline
\end{tabular}

Melalui tingkat kebebasan Faktor Eksternal adalah $(\mathrm{r}-1) \times(\mathrm{c}-1)=(4-1) \times(7-1)=3 \times 6=$ 18 dan tingkat keberartian sebesar $\alpha=0.05$, maka didapat $\chi_{18}^{2}=28.869$. Dari hasil perhitungan tersebut didapat bahwa $\chi^{2}<\chi_{18}^{2}$, sehingga $\mathrm{H}_{0}$ diterima atau $\mathrm{H}_{1}$ ditolak. Kesimpulan yang diperoleh adalah tidak adanya saling kebergantungan antara variabel Faktor Internal terhadap variabel keputusan konsumen dalam menggunakan VoIP.

Pengujian Faktor Pribadi menggunakan variabel hasil penelitian berupa biaya pemakaian telekomunikasi responden selama 1 bulan (kuesioner no. 17) dengan variabel penggunaan VoIP (kuesioner no. 7) seperti ditunjukkan pada tabel berikut. 
Tabel 17 Frekuensi Observasi $\left(\boldsymbol{f}_{\mathbf{0}}\right)$ Faktor Pribadi Responden

\begin{tabular}{|c|c|c|c|c|c|c|c|c|c|}
\hline \multirow{2}{*}{\multicolumn{2}{|c|}{ Menggunakan VoIP }} & \multicolumn{7}{|c|}{ Perangkat Lunak Yang Dipakai } & \multirow[b]{2}{*}{$\Sigma$} \\
\hline & & Cubix & Idefisk & $\begin{array}{c}\text { SJ } \\
\text { Phone }\end{array}$ & Xlite & $\begin{array}{c}\text { YM } \\
!\end{array}$ & $\begin{array}{c}\text { Gmail } \\
\text { Talk }\end{array}$ & Lainnya & \\
\hline \multirow{6}{*}{$\begin{array}{l}\text { Rata-Rata } \\
\text { Biaya } \\
\text { Komunikasi } \\
1 \text { Bulan }\end{array}$} & $<50,000$ & 0 & 0 & 3 & 2 & 84 & 8 & 16 & 113 \\
\hline & $\begin{array}{l}50,000 \mathrm{~s} / \mathrm{d} \\
100,000\end{array}$ & 0 & 2 & 6 & 8 & 145 & 13 & 34 & 208 \\
\hline & $\begin{array}{l}100,001 \mathrm{~s} / \mathrm{d} \\
500,000\end{array}$ & 1 & 1 & 1 & 2 & 119 & 12 & 22 & 158 \\
\hline & $\begin{array}{l}500,001 \mathrm{~s} / \mathrm{d} \\
1,000,000\end{array}$ & 0 & 0 & 0 & 1 & 12 & 1 & 1 & 15 \\
\hline & $>1,000,000$ & 0 & 0 & 0 & 0 & 4 & 0 & 1 & 5 \\
\hline & $\Sigma$ & 1 & 3 & 7 & 11 & 280 & 26 & 58 & 386 \\
\hline
\end{tabular}

Tabel 18 Frekuensi Harapan $\left(\boldsymbol{f}_{\boldsymbol{e}}\right)$ Faktor Pribadi Responden

\begin{tabular}{|c|c|c|c|c|c|c|c|c|}
\hline \multirow{2}{*}{\multicolumn{2}{|c|}{ Menggunakan VoIP }} & \multicolumn{7}{|c|}{ Perangkat Lunak Yang Dipakai } \\
\hline & & Cubix & Idefisk & $\begin{array}{c}\text { SJ } \\
\text { Phone }\end{array}$ & Xlite & YM! & $\begin{array}{l}\text { Gmail } \\
\text { Talk }\end{array}$ & Lainnya \\
\hline \multirow{5}{*}{$\begin{array}{l}\text { Rata-Rata } \\
\text { Biaya } \\
\text { Komunikasi } \\
1 \text { Bulan }\end{array}$} & $<50,000$ & 0.29 & 0.88 & 2.05 & 3.22 & 81.97 & 7.61 & 16.98 \\
\hline & $\begin{array}{l}50,000 \mathrm{~s} / \mathrm{d} \\
100,000\end{array}$ & 0.54 & 1.62 & 3.77 & 5.93 & 150.88 & 14.01 & 31.25 \\
\hline & $\begin{array}{l}100,001 \mathrm{~s} / \mathrm{d} \\
500,000\end{array}$ & 0.41 & 1.23 & 2.87 & 4.50 & 114.61 & 10.64 & 23.74 \\
\hline & $\begin{array}{l}500,001 \mathrm{~s} / \mathrm{d} \\
1,000,000\end{array}$ & 0.04 & 0.12 & 0.27 & 0.43 & 10.88 & 1.01 & 2.25 \\
\hline & $>1,000,000$ & 0.01 & 0.04 & 0.09 & 0.14 & 3.63 & 0.34 & 0.75 \\
\hline
\end{tabular}

Frekuensi Harapan $\left(f_{e}\right)$ didapat dari $f_{e}=\frac{\text { row total } x \text { column total }}{n}$

Tabel 19 Perhitungan $\chi^{2}$ Faktor Pribadi Responden

\begin{tabular}{|c|c|c|c|c|c|c|c|c|}
\hline \multirow{2}{*}{\multicolumn{2}{|c|}{ Menggunakan VoIP }} & \multicolumn{7}{|c|}{ Perangkat Lunak Yang Dipakai } \\
\hline & & Cubix & Idefisk & $\begin{array}{c}\text { SJ } \\
\text { Phone }\end{array}$ & Xlite & YM! & $\begin{array}{l}\text { Gmail } \\
\text { Talk }\end{array}$ & Lainnya \\
\hline \multirow{5}{*}{$\begin{array}{l}\text { Rata-Rata } \\
\text { Biaya } \\
\text { Komunikasi } \\
1 \text { Bulan }\end{array}$} & $<50,000$ & 0.29 & 0.88 & 0.44 & 0.46 & 0.05 & 0.02 & 0.06 \\
\hline & $\begin{array}{l}50,000 \mathrm{~s} / \mathrm{d} \\
100,000\end{array}$ & 0.54 & 0.09 & 1.32 & 0.72 & 0.23 & 0.07 & 0.24 \\
\hline & $\begin{array}{l}100,001 \mathrm{~s} / \mathrm{d} \\
500,000\end{array}$ & 0.85 & 0.04 & 1.21 & 1.39 & 0.17 & 0.17 & 0.13 \\
\hline & $\begin{array}{l}500,001 \mathrm{~s} / \mathrm{d} \\
1,000,000\end{array}$ & 0.04 & 0.12 & 0.27 & 0.77 & 0.12 & 0.00 & 0.70 \\
\hline & $>1,000,000$ & 0.01 & 0.04 & 0.09 & 0.14 & 0.04 & 0.34 & 0.08 \\
\hline
\end{tabular}

$$
\chi^{2}=12.13
$$

Melalui tingkat kebebasan Faktor Pribadi adalah $(\mathrm{r}-1) \times(\mathrm{c}-1)=(5-1) \times(7-1)=4 \times 6=$ 24 dan tingkat keberartian sebesar $\alpha=0.05$, maka didapat $\chi_{24}^{2}=36.415$. Dari hasil perhitungan tersebut didapat bahwa $\chi^{\mathbf{2}}<\chi_{24}^{2}$, sehingga $\mathrm{H}_{0}$ diterima atau $\mathrm{H}_{1}$ ditolak. Kesimpulan yang diperoleh adalah tidak adanya saling kebergantungan antara variabel Faktor Pribadi terhadap variabel keputusan konsumen dalam menggunakan VoIP. 


\section{Persepsi Responden}

Persepsi merupakan bagian faktor internal psikologis dari responden. Dalam hal ini, persepsi yang dimaksud adalah pandangan responden terhadap VoIP setelah mengetahui ataupun memakainya. Beberapa hal yang menjadi perhatian pada persepsi responden pada penelitian ini (kuesioner no. 23 28) ditampilkan pada tabel berikut.

Tabel 20 Daftar Persepsi Responden Terhadap VoIP

\begin{tabular}{|c|c|c|}
\hline Persepsi & Ya & Tidak \\
\hline $\begin{array}{l}\text { Responden akan menggunakan VoIP jika harganya lebih murah dari operator yang } \\
\text { ada sekarang (baik hanya sebatas sambungan interlokal atau internasional) }\end{array}$ & $86.0 \%$ & $14.0 \%$ \\
\hline $\begin{array}{l}\text { Responden bersedia menggunakan kartu operator yang menunjang koneksi Internet } \\
\text { untukmenggunakan VoIP }\end{array}$ & $66.2 \%$ & $33.8 \%$ \\
\hline $\begin{array}{l}\text { Responden bersedia mengganti handphone atau melakukan pemasangan Internet } \\
\text { pada komputer untuk menggunakan VoIP }\end{array}$ & $73.5 \%$ & $26.5 \%$ \\
\hline $\begin{array}{l}\text { Responden bersedia melakukan instalasi perangkat lunak (jika gratis dan mudah) } \\
\text { pada komputer/handphone untuk menggunakan VoIP }\end{array}$ & $94.2 \%$ & $5.8 \%$ \\
\hline $\begin{array}{l}\text { Responden bersedia terhubung dengan Internet saat sebagai penerima panggilan } \\
\text { sekaligus menanggung biaya Internet }\end{array}$ & $59.5 \%$ & $40.5 \%$ \\
\hline $\begin{array}{l}\text { Responden tetap menggunakan GSM/CDMA/PSTN walaupun telah menggunakan } \\
\text { VoIP }\end{array}$ & $88.8 \%$ & $11.2 \%$ \\
\hline
\end{tabular}

Berdasarkan hasil penelitian (kuesioner no. 29), responden akan meninggalkan penggunaan VoIP apabila biaya pemakaian jaringan lain lebih murah, munculnya teknologi telekomunikasi lain, kualitas suara jaringan lain lebih baik, dan VoIP sulit dioperasikan. Persentase faktor yang akan membuat responden meninggalkan penggunaan VoIP ditampilkan pada gambar di bawah ini.

Hal yang menarik adalah $77.8 \%$ responden bersedia merekomendasikan penggunaan VoIP kepada rekan/saudara mereka. Hasil penelitian ini (kuesioner no. 30) ditampilkan pada gambar di bawah ini.

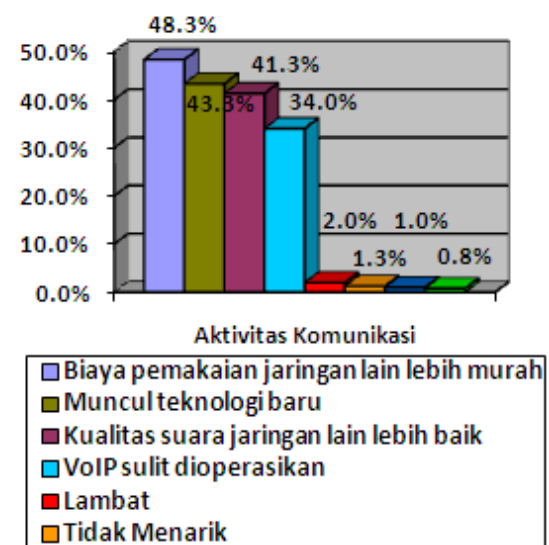

Gambar 23 Faktor yang Membuat

Responden Meninggalkan VoIP

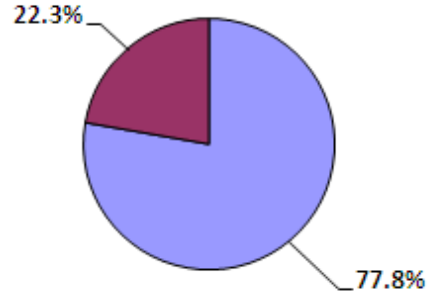

口Akan Merekomendasikan VolP

口Tidak Merekomendasikan VolP

Akan Merekomendasikan 
Terdapat ketergantungan (dependent) antara Faktor Eksternal terhadap penggunaan VoIP oleh konsumen, sedangkan Faktor Pribadi dan Faktor Internal adalah saling bebas (independent) terhadap penggunaan VoIP. (2) Biaya yang murah dan kemudahan pengoperasian menjadi faktor utama masyarakat untuk mencoba dan terus menggunakan VoIP. (3) Penggunaan VoIP untuk area lokal adalah tidak menguntungkan bila dibandingkan dengan penggunaan sesama operator GSM/CDMA/PSTN, selain itu, lebih menguntungkan bila menggunakan VoIP. (4) Penggunaan VoIP untuk area interlokal adalah tidak menguntungkan bila dibandingkan dengan penggunaan sesama operator GSM/CDMA, selain itu lebih menguntungkan bila menggunakan VoIP. (5) Pengunaan VoIP untuk area internasional lebih menguntungkan bila dibandingkan dengan operator GSM/CDMA/PSTN (dalam segala kondisi). (6) Pengguna VoIP akan terus berkembang. Hal ini dapat dilihat dari hasil penelitian bahwa masyarakat bersedia menggunakan kartu operator yang menunjang koneksi Internet, mengganti perangkat keras untuk mendukung pemakaian VoIP, bersedia terhubung dengan Internet sekaligus menanggung biaya saat sebagai penerima, dan akan merekomendasikan VoIP kepada rekan/saudaranya. (7) Masyarakat akan tetap menggunakan GSM/CDMA/PSTN walaupun telah menggunakan VoIP. Hal ini tentunya tidak akan menyebabkan penurunan yang signifikan terhadap konsumsi jasa komunikasi melalui operator-operator tersebut.

\section{SIMPULAN}

Dari hasil penelitian yang telah dilakukan maka dapat disimpulkan sebagai berikut: (1) Terdapat ketergantungan (dependent) antara Faktor Eksternal terhadap penggunaan VoIP oleh konsumen, sedangkan Faktor Pribadi dan Faktor Internal adalah saling bebas (independent) terhadap penggunaan VoIP. (2) Biaya yang murah dan kemudahan pengoperasian menjadi faktor utama masyarakat untuk mencoba dan terus menggunakan VoIP. (3) Penggunaan VoIP untuk area lokal adalah tidak menguntungkan bila dibandingkan dengan penggunaan sesama operator GSM/CDMA/PSTN, selain itu, lebih menguntungkan bila menggunakan VoIP. (4) Penggunaan VoIP untuk area interlokal adalah tidak menguntungkan bila dibandingkan dengan penggunaan sesama operator GSM/CDMA, selain itu lebih menguntungkan bila menggunakan VoIP. (5) Pengunaan VoIP untuk area internasional lebih menguntungkan bila dibandingkan dengan operator GSM/CDMA/PSTN (dalam segala kondisi). (6) Pengguna VoIP akan terus berkembang. Hal ini dapat dilihat dari hasil penelitian bahwa masyarakat bersedia menggunakan kartu operator yang menunjang koneksi Internet, mengganti perangkat keras untuk mendukung pemakaian VoIP, bersedia terhubung dengan Internet sekaligus menanggung biaya saat sebagai penerima, dan akan merekomendasikan VoIP kepada rekan/saudaranya. (7) Masyarakat akan tetap menggunakan GSM/CDMA/PSTN walaupun telah menggunakan VoIP. Hal ini tentunya tidak akan menyebabkan penurunan yang signifikan terhadap konsumsi jasa komunikasi melalui operator-operator tersebut.

Berdasarkan hasil penelitian ini, maka saran yang diberikan kepada pihak penyedia VoIP, pemerintah, pengguna, dan pihak yang akan melanjutkan penelitian ini adalah sebagai berikut: (1) Penyedia VoIP seperti VoIP Rakyat sebaiknya mengadakan iklan dan promosi yang lebih intensif.

(2) Penyedia VoIP diharapkan memberikan panduan penggunaan dan penanganan kesulitan yang mudah dipahami. (3) Pemerintah dan operator hendaknya melakukan perbaikan infrastruktur jaringan Internet dan menurunkan tarif Internet di Indonesia. (4) Pemerintah diharapkan memperjelas regulasi tentang penyediaan VoIP. (5) Masyarakat diharapkan membantu penyedia VoIP untuk merekomendasikan penggunaan VoIP kepada pihak lain agar memacu pemerintah dan ISP lain memperbaiki infrastruktur jaringan Internet dan menurunkan tarif Internet.(6) Para peneliti lanjutan diharapkan memperluas lokasi penelitian dan melakukan analisis terhadap kualitas suara dan biaya investasi perangkat keras. 


\section{DAFTAR PUSTAKA}

Alwakeel, S., Prasetijo, A. (2009). A policy-based admission control scheme for voice over IP networks. J. Comput. Sci, 5, 817-821.

Berkeley Lab. (2008). Tariff. A US Department of Energy National Laboratory Article, diakses 1 Juni 2008 dari http://tariffs.lbl.gov/notes/definitions.php

Cisco Systems. (2004). VoIP Provider. Routing Glossary List, diakses 1 Juni 2008 dari http://newsroom.cisco.com/dlls/2004/hd 051904c.html

Goncalves, M. (1999). Voice Over IP Networks. New York: McGraw-Hill.

Hasan, M. I. (2002). Pokok-pokok Materi Metodologi Penelitian dan Aplikasinya. Bogor: Ghalia Indonesia.

Hidayat, W. (2003). VoIP dan Telepon Masa Depan. Detik-inet, diakses 20 Januari 2009 dari http://www.detikinet.com/read/2003/10/13/180000/117104/112/voip-dan-telepon-masa$\underline{\text { depan }}$

Levine, D., Stephan, D., Krehbiel, T., Berenson, M. (2005). Statistics for Managers Using Microsoft ${ }^{\circledR}$ Excel. New Jersey: Prentice Hall.

Purbo, O. W. (2007). VoIP: Cikal Bakal “Telkom Rakyat”. Jakarta: Info Komputer

Purwanto, E., Tim Sub Bag Jaringan Informasi IPTEK. (2008). Pengantar Pengertian Internet. Litbang Depkes, $\quad$ diakses $\quad 1 \quad$ Juni $\quad 2008$ dari http://209.5.175.104/search?q=cache:GXQW5M2wfAJ:www.litbang.depkes.go.id/tik/media/ Pengantar_WWW.doc + pengertian+Internet\&hl=id\&ct=clnk\&cd=10\&gl=id\&client=firefox$\underline{\mathrm{a}}$

Pustekkom Depdiknas. (2007). VoIP. Edukasi Pustekkom, diakses 1 Juni 2008 dari http://www.edukasi.net/pengpop/pp full.php?ppid=298\&fname=semua.html

Rahardja, A. 24 Mei, (2007). Telepon Gratis Via VoIP Rakyat. Kompas, hlm16.

Ravichandran, T., Samy, K.D. (2006). Performance Enhancement on Voice using VAD Algorithm and Cepstral Analysis. J. Comput. Sci. 2: 835-840.

Schiffman, L. G., Kanuk, L. L. (2007). Consumer Behavior. Edisi 9. New Jersey: Prentice Hall

Singh, G., Atwal, A. P. S., Sohis, B. S. (2007). Mobility management technique for real time traffic in 802.11 Networks. J. Comput. Sci., 3, 390-398. 